\title{
Sistem Kendali Palang Pintu Otomatis Menggunakan Barcode Berbasis Mikrokontroler Atmega 328p-Pu Pada Pintu Masuk Perpustakaan Unila
}

\author{
Remy Martin 1), Dr.Eng,Dikpride Despa,S.T.,M.T2), Dr. Eng. Mardiana, S.T.,M.T ${ }^{3)}$ \\ 1,2,3 Jurusan Teknik Elektro Universitas Lampung, Bandar Lampung \\ Jl. Prof. Sumantri Bojonegoro No. 1 Bandar Lampung 35145 \\ remyaja11.11@gmail.com
}

\begin{abstract}
ABSTRAK- Perpustakaan merupakan sarana penting bagi lembaga pendidikan seperti halnya Universitas Lampung. Fasilitas perpustakaan yang memadai akan memberikan rasa nyaman bagi pengunjung dan juga akan meningkatkan akreditasi. Salah satu aspek penting yang menjadi tolak ukur keberhasilan unit perpustakaan adalah banyaknya jumlah pengunjung. Pada kasus perpustakaan di Universitas Lampung proses absensi pengunjung dilakukan dengan menggunakan sistem scanner barcode. Cara ini dinilai efektif dan efisien karna dapat menghemat waktu dan menimalisir antrian. Namun karena tidak adanya sistem yang mengharuskan absensi. Oleh karena itu diperlukan sistem yang membantu perpustakaan agar pengunjung melakukan absensi secara otomatis ketika saat masuk keperpustakaan. Dengan memanfaatkan fungsi dari mikrokontroler pada penelitian maka dibuat sebuah Sistem Kendali Palang Pintu Otomatis Menggunakan Barcode Berbasis Mikrokontroler Atmega 328p-Pu. Palang pintu otomatis ini dirancang menggunakan scanner barcode, sensor ultrasonik, Mikrokontroler Atmega 328p-Pu, dan motor servo. Dan untun pengendalian motor servo dibuat dengan menambahkan Mikrokontroler Atmega 328p-pu yang menggunakan program Arduino dengan bahasa C. Pemasangan sistem kendali palang pintu otomatis dipintu masuk perpustakaan unila dapat memberikan kontribusi dalam proses penertiban dan pendataan mahasiswa yang masuk keperpustakaan unila. Sistem yang di buat masih terdapat beberapa kendala, seperti kartu dengan label barcode yang sudah rusak akaan memerlukan waktu yang agak lama pada saat scanner.
\end{abstract}

Kata kunci : Mikrokontroler Atmega 328p-pu, sensor Ultrasonic, Motor Servo, Scanner Barcode, dan UPT- Perpustakaan Unila.

ABSTRACT-Libraries are an important means for educational institutions such as the University of Lampung. Library facilities will provide comfort for visitors and will also increase the accreditation. One important aspect that is a benchmark for the success of the library unit is the large number of visitors. In the case of the library at the University of Lampung visitor attendance processing done using barcode scanner systems. This was seen as effective and efficient as it can save time and minimize queuing. However, due to the absence of a system that requires attendance. However, due to the absence of a system that requires attendance. However, due to the absence of a system that requires attendance. Therefore we need a system that helps the library for visitors to take attendance automatically when signing in to the library. By leveraging the functionality of a microcontroller on the research, it created an Automatic Door Control System Using Cross Barcode Based Microcontroller Atmega 328p-Pu. Cross automatic doors is designed using a barcode scanner, ultrasonic sensor, Microcontroller Atmega 328p-Pu and servo motors. And to control servo motors made by adding Microcontroller Atmega 328p-pu that use Arduino program in $C$ Installation of automatic control systems doorstop at the entrance to the library Unila can contribute to the process control and data collection on students who entered the library Unila. Systems that are made there are still some obstacles, such as a card with a barcode label that has been damaged akaan require a longer period of time when the scanner.

Keywords: Microcontroller Atmega 328p-pu, Ultrasonic sensors, Servo Motor, Barcode Scanner, and UPT-Unila Library. 


\section{PENDAHULUAN}

Perpustakaan merupakan sarana penting bagi lembaga pendidikan seperti halnya Universitas Lampung. Fasilitas perpustakaan yang memadai akan memberikan rasa nyaman bagi pengunjung dan juga akan meningkatkan akreditas Universitas tersebut. Salah satu aspek penting yang menjadi penilaian kinerja unit perpustakaan adalah banyaknya jumlah pengunjung. Pada kasus perpustakaan di Universitas Lampung proses absensi pengunjung dilakukan dengan menggunakan sistem Scanner Barcode. Cara ini dinilai efektif dan efisien karena dapat menghemat waktu dan meminimalisir antrian. Dari kekurangan yang dilihat maka penelitian ini bermaksud merancang berupa model kendali pintu otomatis menggunakan barcode. Dengan dirancangnya model sistem kendali pintu otomatis menggunakan barcode ini bisa memberikan gambaran kemudahan untuk melakukan monitoring dan menciptakan ketertiban di dalam Perpustakaan Unila.

\section{TINJAUAN PUSTAKA}

\subsection{MikrokontrolerATMega 328p-pu}

Mikrokontroler ATMega 328p-pu adalah keluaran dari mikrokontroler atmel yang memiliki arsitektur RISC (Reduce InstructionSet Computer) yang dimana setiap proses eksekusi data lebih cepat dari pada arsitektur CISC (Completed Instruction Set Computer). Mikrokontroller jenis ATmega 328p-pu ini memiliki konfigurasi berupa keterangan nama keluaran dari PIN. Berikut tampilan nama PIN pada mikrokontroller jenis Atmega 328p-pu tersebut[1]:

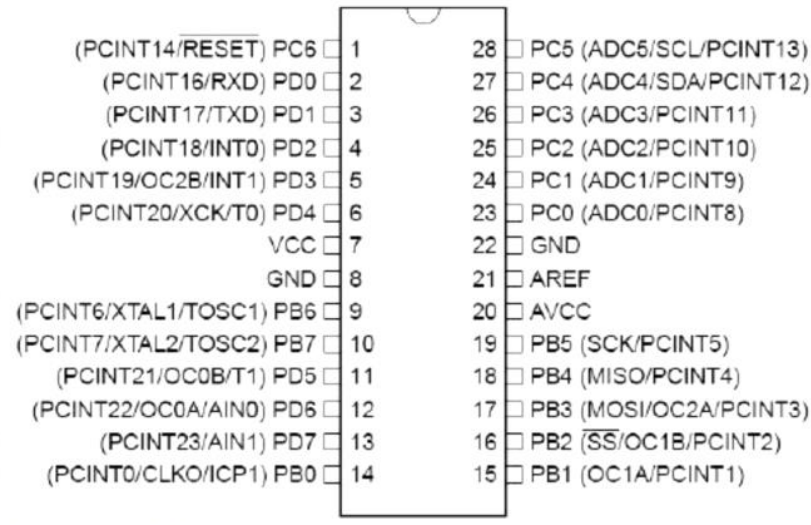

Gambar 1. Konfigurasi PIN mikrokontroler ATmega 328

\subsection{Motor Servo}

Motor servo ialah berupa motor dengan sistem umpan balik tertutup di mana letak dari motor segera diinformasikan kembali ke rangkaian kontrol yang ada di dalam motor servo. Motor servo merupakan salah satu jenis motor DC. Diantaranya berupa motor stepper, motor servo berkerja secara close loop. Poros motor dikaitkan dengan rangkaian kendali, selanjutnya bila putaran poros belum sampai pada tempat yang diinginkan maka rangkaian kendali akan terus mencari tempat hingga mencapai tempat yang diinginkan. Motor servo banyak dipakai pada peranti R/C (remote control) seperti mobil, pesawat, helikopter, dan kapal, serta sebagai aktuator robot maupun penggerak pada kamera.

\subsection{Prisp Kerja Motor Servo}

Pada motor servo yang sangat sederhana hanya menggunakan posisi penginderaan melalui potensio meter dan bang-bang kontrol pada motor, motor selalu berputar pada kecepatan penuh (atau dihentikan). Jenis motor servo tidak banyak digunakan dalam kontrol gerak industri, tetapi mereka membentuk dasar dari servo yang sederhana dan murah yang digunakan untu ke radio control model. Servo motor yang lebih canggih mengukur baik posisi dan juga kecepatan poros output. Mereka juga dapat mengontrol kecepatan motor mereka, dari pada selalu berjalan dengan kecepatan penuh. Kedua perangkat tambahan, biasanya dalam kombinasi dengan algoritma control PID, memungkinkan servo motor yang akan dibawa keposisinya memerintahkan lebih cepat dan lebih tepat, dengan over shoot kurang[2]. 


\subsection{Scanner Barcode}

Barcode atau kode batang adalah sekumpulan data yang digambarkan dengan garis dan jarak spasi (ruang). Barcode menggunakan urutan garis batang vertikal dan jarak antara garis untuk mewakili angka atau simbol lainnya. Dengan demikian, setiap ketebalan garis batang dan jarak antara garis saru dengan yang lain selalu berbeda sesuai dengan isi data yang dikandung oleh kode batang atau Barcode tersebut.

\subsection{Sensor Ultrasonik}

Pada dasanya, Sensor Ultrasonik / Ping sensor terdiri dari sebuah chip pembangkit sinyal $40 \mathrm{KHz}$, sebuah speakerultrasonik dan sebuah mikropon ultrasonik. Speaker ultrasonik mengubah sinyal $40 \mathrm{KHz}$ menjadisuara sementara mikropon ultrasonik berfungsi untuk mendeteksi pantulan suaranya. Pada modulPing sensor terdapat 3 pin yang digunakan untuk jalur power supply $(+5 \mathrm{~V})$, ground dan signal. Pin signaldapat langsung dihubungkan dengan mikrokontroler tanpa tambahan komponen apapun.

\section{METODE PENELITIAN}

\subsection{Waktu dan Tempat}

Penelitian dan rancangan Penelitian dilakukan di UPT Perpustakaan Universitas Lampung dan mulai dilaksanakan Bulan Desember 2014 dan direncanakan selesai pada Bulan April 2015

\subsection{Tahap-Tahap pelaksanaan Penelitian}

Dalam penyelesaian Penelitian Model Sistem Kendali Palang Pintu Otomatis Menggunakan Barcode ini menggunakan langkah kerja yang dijelaskan sebagai berikut :

1. Sistem pengunji palang pintu

Dari hasil analisa kebutuhan berdasarkan bentuk dan daya palang pintu digunakan sistem pengunci menggunakan palang buka tutup otomatis menggunakan motor servo.

2. Program kendali

Program kendali digunakan Mikrokontroler dengan spesifikasi data ringan dan ukuran kecil. Oleh karena itu digunakan Mikrokontroler Atmega 328ppu dengan menggunakan program Arduino IDE.
3. Indikasi

Diperlukan sebuah indikator yang mudah dimengerti bagi pengunjung pada saat posisi palang pintu terkunci atau terbuka. Indikator yang digunakan pada sistem ini digunakan lampu indikator (lampu merah $=$ terkunci dan lampu hijau $=$ terbuka).

4. Komunikasi dan interaksi barcode

Pada perpustakaan Universitas Lampung sistem antarmuka dan barcode telah tersedia. Untuk itu untuk saat ini interaksi barcode dan Mikrokontroler dapat dilakukan melalui isyarat sinyal barcode terdeteksi scanner.

\subsection{Perancangan Blok Diagram Sistem}

Perancangan blok diagram dilakukan dengan tujuan untuk mempermudah realisasi sistem yang akan dibuat. Blok diagram sistem kendali pintu otomatis berbasis barcode. Perancangan blok dimulai dari mahasiswa pemegang kartu yang telah divalidasi / terdaftar diperpustakaan atau pengunjung umum, kemudian pengunjung tersebut diwajibkan melakukan scanner kartu identitas terlebih dahulu pada barcode scanner sebelum masuk ke perpustakaan. Pada scanner akan dibaca kode yang terkandung pada garisgaris bar dikartu yang kemudian sebagai data absen yang dikirimkan ke database sebagai pengunjung terdaftar atau pengunjung umum. Barcode scanner akan mengirimkan sinyal isyarat kepada Mikrokontroler untuk memberikan perintah pada driver motor untuk membuka palang pintu. Palang pintu akan secara otomatis terkunci kembali setelah sensor ultrasonik mendeteksi satu orang telah masuk dan tidak terdeteksi adanya orang di depan palang pintu. 


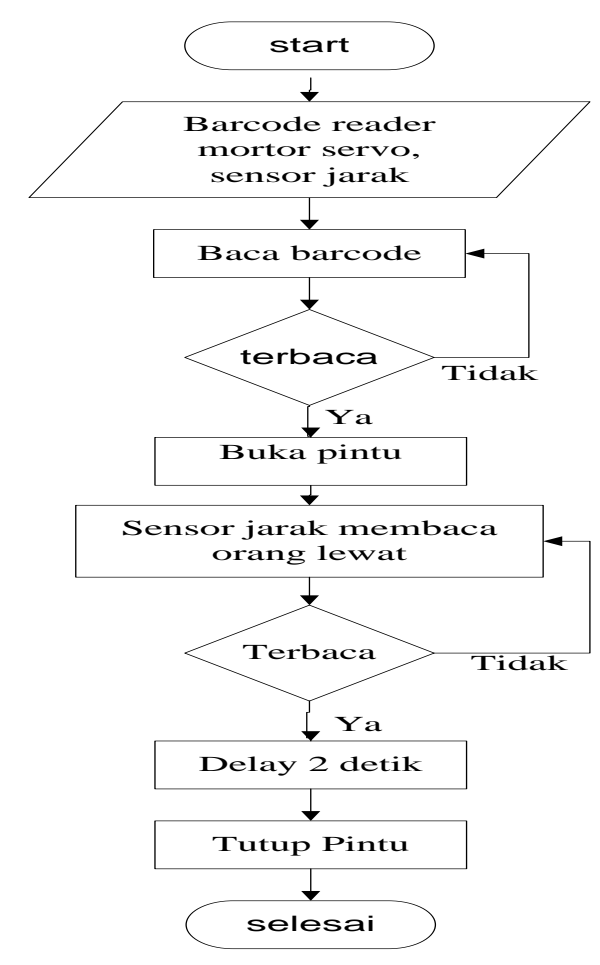

Gambar 2. Flowchat sistem kendali palang pintu otomatis berbasis barcode dan Mikrokontroler Atmega 328p-pu

Pada gambar 2 diatas menjelaskan cara kerja pada sistem kendali palang pintu otomatis berbasis barcode dan Mikrokontroler Atmega 328p-pu. Cara kerja palang pintu otomatis bekerja jika saat alat scanner barcode diberikan pulsa, maka sinyal akan di terima oleh arduino member sinyal perintah kepada motor servo untuk membuka palang pintu yang telah diberi masukan terbuka $90^{\circ}$, palang pintu akan tertutup apa bila sensor menerima benda bergerak pada jarak jangkau sensor dan masuk ke arduino maka motor servo akan menutup palang pintu $90^{\circ}$

\section{HASIL DAN PEMBAHASAN}

Hasil dan pembahasan mengenai pengujian perencanaan alat yang akan dibuat, tujuan dari pengujian alat ini adalah untuk membuktikan apakah sistem yang dirancang memenuhi spesifikasi yang telah direncanakan, pengujian ini meliputi
a) Blok Diagram Rangkain
b) Pembahasan Analisa Kebutuhan
c) Pengujian Rangkaian Hardware

\subsection{Blok Diagram Rangkain}

Alat yang telah dibua ada tiga rangkaian. Rangkaian yang pertama adalah rangkaian mikrokontroller (minimum system) ATMega 328p- pu yang merupakan otak dari alat ini. Rangkaian mikrokontroler ini berupa rangkaian sistem minimun ATMega 328p-pu. Terdapat juga IC ATMega 328p-pu yang berfungsi untuk menyimpan program. Rangkaian kedua adalah rangkain barcode Rangkain ini tidak dibuat sendiri melainkan menggunakan alat yang dapat membaca kode pada barcode dan menjadi inputan untuk membuka palang pintu. Rangkaian yang ketiga adalah rangkaian motor servo dan sensor dengan IC sebagai driver motor servo. Rangkaian ini merupakan keluaran dari rangkaian mikrokontroler. Rangkaian ini berisi motor servo yang berfungsi menggerakkan pintu secara otomatis.

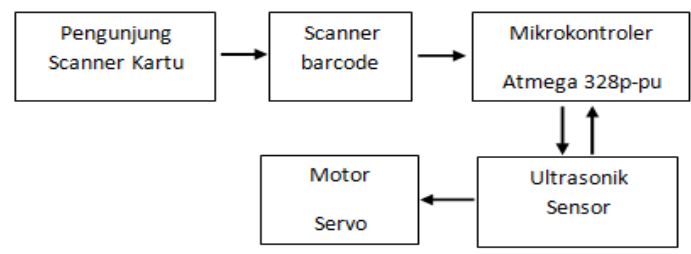

Gambar 3. Blok Diagram Rangkaian

Pada gambar 3. Menjelaskan fungsi blok diagram rangkain, sebagai berikut:

1. Barcode berfungsi sebagai inputan pada mikrokontroler dan memerintahkan motor untuk membuka palang pintu.

2. Sensor gerak berfungsi sebagai pemberi informasi kepada mikrokontroler untuk motor menutup kembali palang pintu.

3. mikrokontroler ATMega 328p-pu yang merupakan otak dari alat sehingga motor dapat berputar.

\subsection{Pembahasan Kebutuhan}

\section{Analisa}

Saat ini belum terdapat sebuah sistem untuk mengantisipasi masalah yang terdapat diperpustakaan, yaitu tentang masalah aktifitas mahasiswa diluar jam kuliah.

Sistem yang dibuat juga dapat mencatat laporan mahasiswa yang melakukan aktifitas diluar jam kuliah. Laporan kehadiran ini didapat pada saat mahasiswa 
melakukan scanning kartu untuk membuka pintu.

\subsection{Pembuatan ATMega 328}

Pembuatan Coding ATMega 328p-pu Pembuatan program yaitu program untuk Arduino UNO, Pembuatan Program Arduino ditulis dengan bahasa $\mathrm{C}$ menggunakan software Arduino. Pada Arduino IDE terdapat 2 fungsi yaitu : 1. Fungsi void setup() Pada fungsi void setup() ini akan ditetapkan tipe data yang masuk, pin yang digunakan, juga menetapkan pin-pin tersebut sebagai output, untuk memberikan perintah pada arduino dapat di-input seperti keterangan pada gambar 4 dibawah ini :

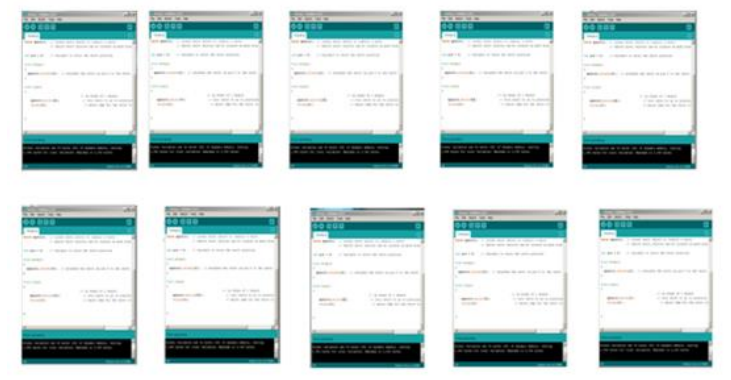

Gambar 4. Fungsi void setup pada Arduino

Pada gambar 4 diatas memberikan keterangan bagai mana arduino dapat berfungsi, pada arduino diberikan inputan, palang pintu otomatis akan bekerja apabila pengunjung datang dan menscan barcode yang ada pada KTM (Kartu Tanda MAhasiswa) maka palang pintu terbuka bekerja sesuai perintah arduino, apabila pengunjung telah melewati sensor yang terpasang dekat palang pintu maka palang pintu tertutup.

\subsection{Pengujian Rangkaian Catu Daya}

Pengujian catu daya ini bertujuan untuk mengecek output tegangan yang di hasilkan oleh masing - masing komponen apakah sudah sesuai dengan perencanaan atau belum, karena apabila tegangan yang dihasilkan melebihi toleransi akan berpotensi menimbulkan beberapa kerusakan pada rangkaian lainnya seperti komponen akan terbakar, sistem dapat tidak berjalan dan lain sebagainya.

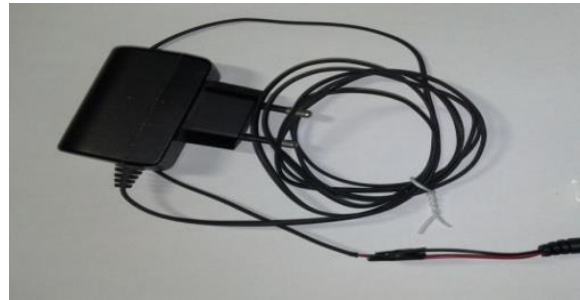

Gambar 5. Fisik Catu Daya

Pada gambar 5 secara umum, istilah "catu daya" berarti satu system filter penyearah (rectifier-filter) yang mengubah tegangan AC menjadi tegangan DC murni. Untuk mencatu micro kontroler, dengan tegangan bolak-balik 220 VAC diubah menjadi tegangan 5 VDC, dibawah ini piranti catu daya 5 VDC 1A:

Tabel 1. Tabel Hasil Pengukuran Catudaya

\begin{tabular}{|c|c|}
\hline $\begin{array}{c}\text { Pengambilan } \\
\text { data ke }\end{array}$ & $\begin{array}{c}\text { IC 7805 } \\
\left(\mathrm{V}_{\mathrm{dc}}\right)\end{array}$ \\
\hline 1 & 4.98 \\
\hline 2 & 4.8 \\
\hline
\end{tabular}

Berdasarkan table 1 hasil pengukuran diatas dapat dihitung prosentase kesalahan yang didapat dari hasil pengukuran diatas dapat dilihat bahwa prosentase kesalahan pada alat masih sangat kecil yaitu $0.4 \%$ sehingga masih baik untuk digunakan. Pada pengujian sistem arduino membutuhkan inputan 5 Volt DC, output tegangan 220 Volt AC ke 5 Volt DC supaya arduino aman untuk sistem kelistrikannya, sehingga program yang ditanamkan pada arduino dapat mengontrol semua aktifitas dari alat tersebut seperti sensor ultrasonic dan mtor servo yang digunakan didalam Power suplay yang digunakan dengan keluaran 5 Volt DC, sehingga aman digunakan pada alat.

\subsection{Pengujian Motor Servo}

Prinsip kerja motor didasarkan pada peletakan suatu konduktor dalam suatu medan magnet. Pembahasan mengenai prinsip aliran medan magnet akan membantu cara kerja dari sebuah motor. Jika suatu konduktor dililitkan dengan kawat berarus maka akan dibangkitkan medan magnet berputar. Kontribusi dari setiap putaran akan merubah intensitas medan magnit yang ada dalam bidang yang tertutup 
kumparan. Dengan cara inilah medan magnit yang kuat terbentuk. Tenaga yang digunakan untuk mendorong flux magnit tersebut disebut Manetomotive Force ( MMF ).

Pengujian ini dilakukan untuk mengetahui kecepatan respon dan daya mekanik yang dihasilkan. Aktuator harus memiliki tingkat daya mekanik yang kuat untuk dapat mengunci dan membuka palang pintu. Oleh karena itu doorlock mengonsumsi daya listrik yang cukup besar sehingga pengujian konsumsi daya dan kecepatan servo juga dirasa perlu dilakukan. Adapun gambar fisik dan table hasil uji.

Tabel 2. Hasil Pengujian Motor Servo

\begin{tabular}{|c|c|c|}
\hline Pulsa & $\begin{array}{c}\text { Motor } \\
\text { Bawah } \\
\text { (derajat) }\end{array}$ & $\begin{array}{c}\text { Motor Atas } \\
\text { (derajat) }\end{array}$ \\
\hline 1100 & 0 & 0 \\
\hline 2000 & 45 & 45 \\
\hline 2800 & 180 & 180 \\
\hline
\end{tabular}

Berdasarkan hasil pengujian motor servo saat motor servo diberikan pulsa sesusai dengan nilai diatas didapat sudut perputaran yang cukup untuk mengerakan kran. Ketika motor servo diberikan pulsa dibawah dan diatas nilai 1100 dan 2800 tidak ada perubahan putaran, sehingga bisa ditarik kesimpulan bahwa nilai 1100 dan 2800 adalah pulsa minimum dan maksimum untuk kedua motor servo tersebut.

Tabel 3. Pengujian Motor Servo

\begin{tabular}{|c|c|}
\hline Sudut Servo & $\begin{array}{c}\text { Tegangan PIN 10 Arduino } \\
\mathrm{V}_{\mathrm{dc}}\end{array}$ \\
\hline 45 & 0.24 \\
\hline 90 & 0.32 \\
\hline 180 & 0.58 \\
\hline 360 & 0.62 \\
\hline
\end{tabular}

Pada table 3 diatas dari hasil ujicoba pada alat palang pintu otomatis dapat dilihat hasil pengujian dari gambar dibawah ini, sebagai berikut.

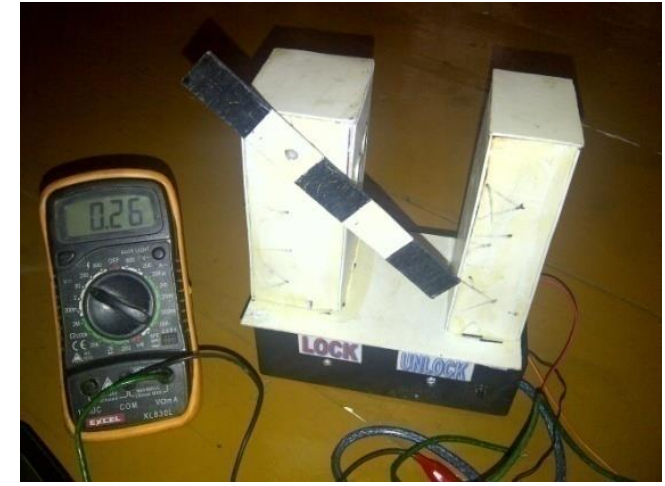

Gambar 6. palang pintu terbuka $45^{0}$ oleh motor servo

Pada gambar 6 pengujian pada motor servo dengan posisi $45^{\circ}$ maka hasil tegangan yang didapat yaitu $0,26 \mathrm{Vdc}$.

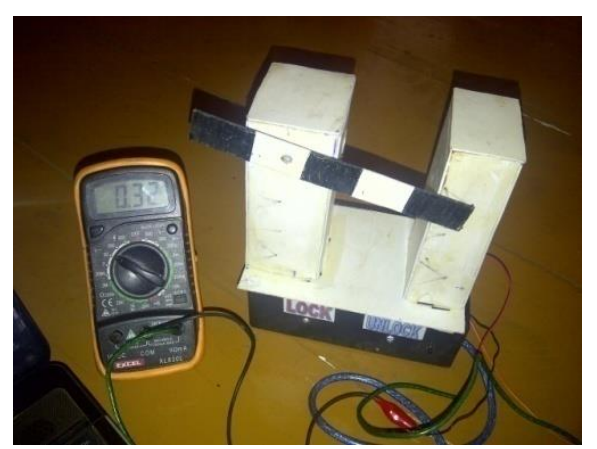

Gambar 7. palang pintu terbuka $90^{\circ}$ oleh motor servo

Pada gambar 7 pengujian pada motor servo dengan posisi $90^{\circ}$ maka hasil tegangan yang didapat yaitu $0,32 \mathrm{Vdc}$.

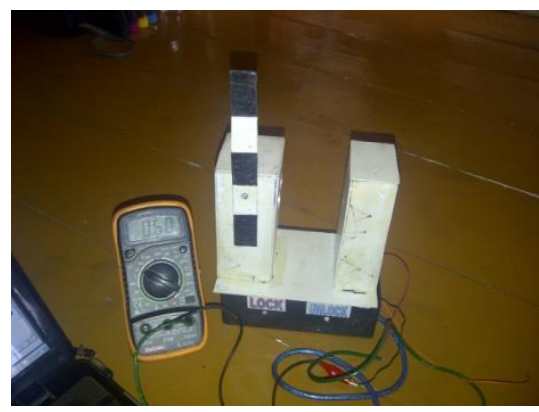

Gambar 8. palang pintu terbuka $180^{\circ}$ oleh motor servo

Pada gambar 8 pengujian pada motor servo dengan posisi $180^{\circ}$ maka hasil tegangan yang didapat yaitu 0,6 Vdc. Pada gambar ini menunjukan palang pintu tertutup dikarenakan sensor ultra sonic mendeteksi adanya gerakan yang diterima, diperoses ke mikrokontroler dan memberikan 
perintah pada motor servo untuk menutup secara otomatis.

\subsection{Pengujian Rangkain Motor Servo}

Pengujian ini dilakukan untuk mengetahui kecepatan respon dan daya mekanik yang dihasilkan. Aktuator harus memiliki tingkat daya mekanik yang kuat untuk dapat mengunci dan membuka palang pintu. Oleh karena itu doorlock mengonsumsi daya listrik yang cukup besar sehingga pengujian konsumsi daya dan kecepatan servo juga perlu dilakukan.

\section{a. Pengujian Keseluruhan Sistem}

Pengujian ini dilakukan untuk mengetahui integrasi semua subsistem apakah sudah berhasil atau tidak dengan menjalankan semua sistem yang telah dirangkai dan diprogram. Nantinya dalam pengujian model ini akan dibuatkan sebanyak 20 kejadian pengujian dan dihitung berapa jumlah kejadian pengujian yang error untuk mengetahui keandalan sistem yang dibuat.
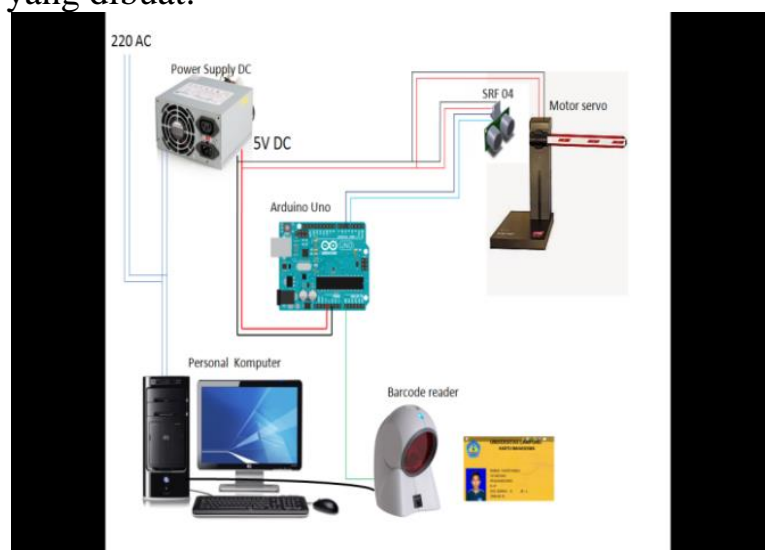

Gambar 9. Keseluruhan Kerja Sistem

Pada gambar 9 tersebut menjelaskan tentang cara kerja system palang pintu otomatis, pengujian dilakukan pada Perpustakaan Universitas Lampung.

Tabel 4. Hasil Uji Keseluruhan Alat

\begin{tabular}{|c|c|c|c|c|c|}
\hline No & Barcode & Led Hijau & Led merah & Sensor jarak & Servo \\
\hline 1 & Tidak Mendeteksi Objek & Hidup & Mati & Berfungsi & Bekerja \\
\hline 2 & Mendeteksi Objek & Mati & Hidup & Berfungsi & Bekerja \\
\hline
\end{tabular}

Pada table 4. diatas maka hasil pengujian yang didapat dari palang pintu otomatis, yang dibuat apakah telah tercapai:

\section{b. Analisa Perbandingan Pengunjung Sebelum Rancangan Alat Dan Sesudah Rancangan Alat.}

Perbandingan dan analisis yang akan dilakukan pada tahap ini adalah membandingkan perbedaan pengunjung perpustakaan pada bulan sebelum dirancangnya alat dan sesudah rancangnya alat.

\subsection{Data Sebelum Pemasangan Palang Pintu Otomatis}

Tampilan data sebelum dipasangnya rancangan alat pengunjung, dapat dilihat pada gambar 10 .

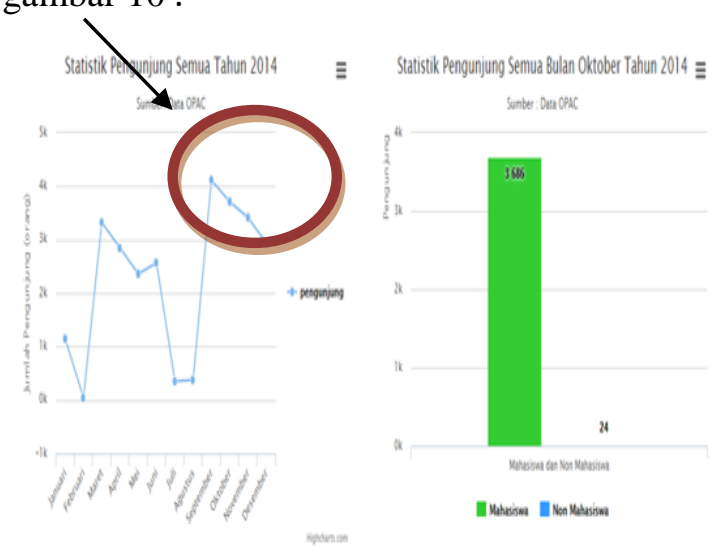

Gambar 10. Data Statistic

Pengujung Perpustakaan

keseluruhan di bulan Oktober 2014

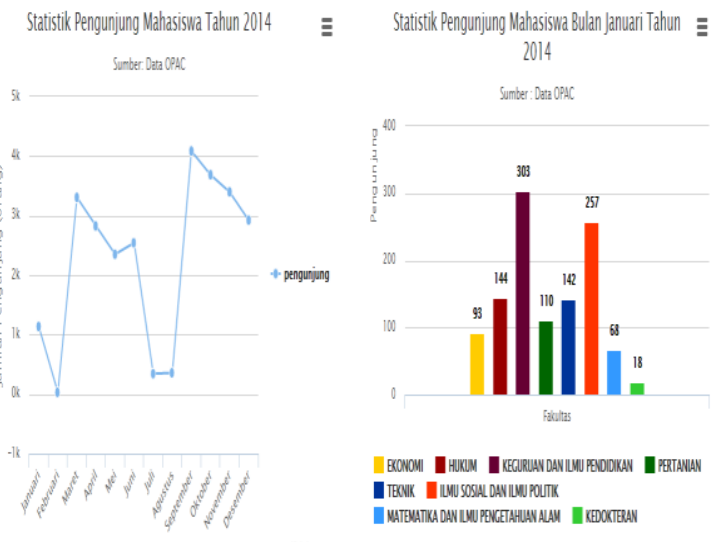

Gambar 11. Data Statistic

Pengujung Perpustakaan mahasiswa di bulan Oktober 2014 


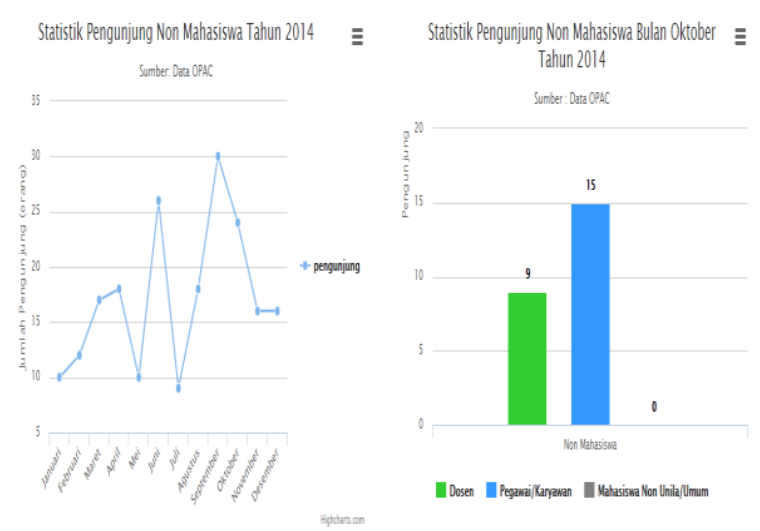

Gambar 12. Data Statistic Pengujung

\subsection{Tampilan \\ Data Setelah \\ Dipasangnya Palang Pintu Otomatis}

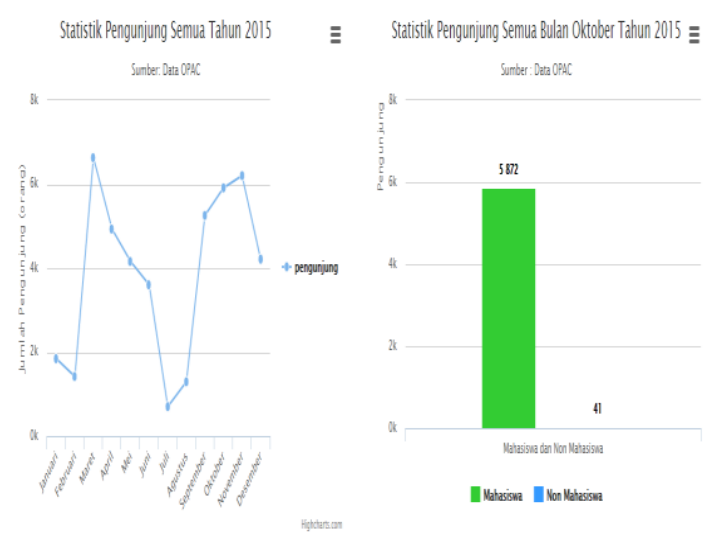

Gambar 13. Data Statistic

Pengujung Perpustakaan keseluruhan di bulan Oktober 2015
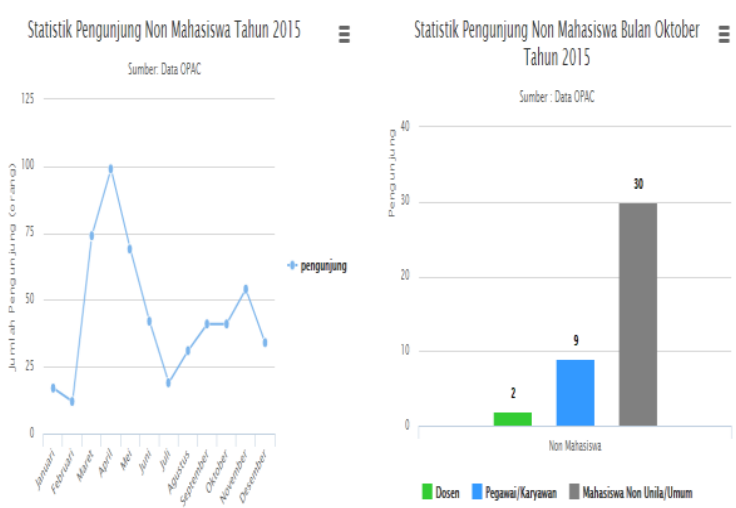

Gambar 14. Data Statistic

Pengujung Perpustakaan non mahasiswa di bulan Oktober 2015

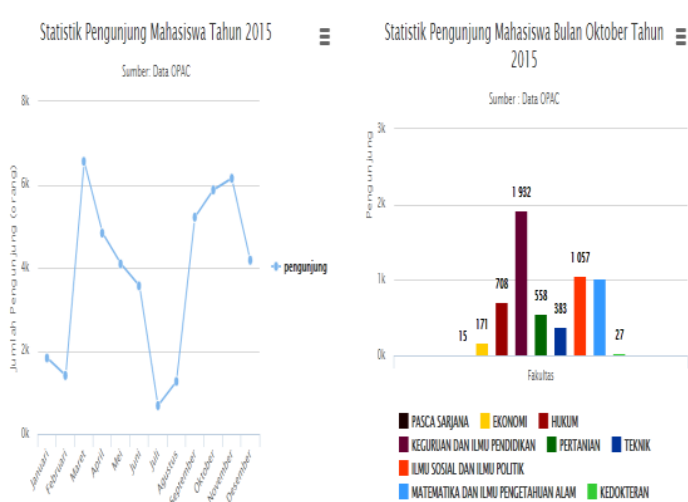

Gambar 15. Data Statistic Pengujung Perpustakaan mahasiswa di bulan Oktober 2015

Dapat dilihat bahwa data pengujung yang terdaftar pada database perpustakaan, Saat dibuat sistem kendali palang pintu otomatis yang bersinergi dengan system barcode, yang digunakan untuk memudahkan proses penertiban dan pedataan mahasiswa. Sistem kedali pintu otomatis ini terpasang pada bulan Oktober akhir dan bulan November 2015. Data pengunjung terjadi peningkatan dikareanakan adanya system yang menharuskan absensi saat mengunjungi perpustakaan. Mahasiswa pemegang kartu yang telah divalidasi / terdaftar diperpustakaan atau pengunjung umum, kemudian pengunjung tersebut diwajibkan melakukan scaning kartuidentitas terlebih dahulu pada barcode scanner sebelum masuk ke perpustakaan.

\section{KESIMPULAN DAN SARAN}

\subsection{Kesimpulan}

Dari serangkaian penelitian yang dilakukan dapat disimpulkan bahwa:

1. Sistem kendali palang pintu otomatis menggunakan scanner barcode dipintu masuk perpustakaan unila. Untuk pengendalian motor servo dibuat dengan menambahkan mikrokontroler Atmega 328p-pu yang menggunakan program 
Arduino ditulis dalam bahasa C mengunakan software Arduino.

2. Pemasangan sistem kendali palang pintu otomatis di pintu masuk perpustakaan unila dapat memberikan kontribusi dalam proses penertiban dan pendataan mahasiswa yang masuk ke perpustakaan unila

3. Sistem yang dibuat masih terdapat beberapa kendala, seperti kartu dengan label barcode yang sudah rusak akan memerlukan waktu yang agak lama pada saat scanner.

\subsection{Saran}

Berdasarkan kendala yang ditemukan pada saat mengaplikasikan model sistem kendali palang pintu otomatis maka disarankan:

1. Penyempurnaan model sistem kendali palang pintu otomatis dengan sumber energi alternatif.

2. Adanya pembahasan kartu anggota (barcode ) agar scanner bisa cepat dilakukan.

\section{DAFTAR PUSTAKA}

1. Bhakti Dinar, Rancang Bangun Mesin Kehadiran Dengan Menggunakan Kode Bar, Bandar Lampung: Universitas Lampung. 2012

2. AkbarulHuda, Mengenal Motorservo, http://akbarulhuda.wordpress.com/2010/ 04/01/mengenal motor servol diupload tanggal 01 April 2010.

3. Hatta Muttaqin, Modul Pengiriman Data Untuk Pemindai Barcode Nirkabel, Bandung: Politeknik Telkom. 2012.

4. Restu Buana, Pembuatan Program Sistem Amplikasi Barkode Pada Proses Monitoring pengiriman Barang Dengan Borland Delphi 7.0, Semarang, Universitas Diponegoro.

5. Bambang Tri Atmojo, Model Sistem Pintu Otomatis Menggunakan Barkode Berbasis PC (Personal Computer) Pada Gerbang Laboratorium Teknik Elektro Unila, Bandar Lampung, Univeersitas Lampung. 2008.

6. Fahmi Aji Wibowo dkk, Laporan Mikroprosesor Sensor Jarak Ultrasonic HC SR04 Dengan Indicator Buzzer dan LED, Akademi Teknik Telekomunikasi, Jakarta, Sandhy Putra Jakarta. 2015.

7. Irigomi, Sejarah dan Manfaat Penggunaan dan Pengertian Barkode, http://irigomi.com/sejarah manfaat pengguna dan pengertian barcode batang.html. diupload 11 Oktober 2011.

8. Dk.Clipart.co.uk,SubjectDesaignTecnolo gy,http://www.clipart.dk.co.uk/733/subjec t/Design Technology Barcode.

9. Idwholesaler,Learning Dictionary ,http://www.idwholesaler.com/learningce nter/dictionarty/main.htm. diupload tanggal 